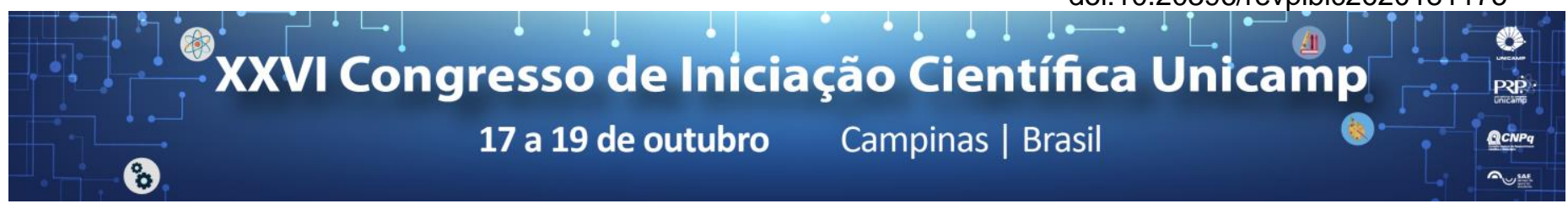

\title{
Brewer's Spent Yeast as Wall Material for Microencapsulation of Food Compounds
}

\author{
Rafaela P. Saturno*, Gabriela V. Marson, Miriam D. Hubinger.
}

\begin{abstract}
The brewer's spent yeast (BSY) hydrolyzed precipitate was used as wall material (WM) for microencapsulation of ascorbic acid (AA) by the spray drying technique. The WM had its centesimal composition (CC) determined as well as some physicochemical (PC) aspects: surface charge, surface tension and glass transition temperature (Tg), in order to study the behavior of the material after being atomized and to identify the most suitable core material. Operational conditions were also studied in the spray dryer. After microencapsulation, a $64 \%$ yield and a microencapsulation efficiency of $100 \%$ were achieved. Microparticle analyses showed low values of water activity and high Tg, indicating absence of microbiological activity and great particle stability at room temperature, respectively, suggesting that this WM is suitable for protecting the ascorbic acid.
\end{abstract}

\section{Key words: \\ Yeast protein hydrolysate, yeast cell wall, microparticle stability.}

\section{Introduction}

Microencapsulation is a technique that can be used to protect food and pharmaceutical compounds against degradation caused mainly by moisture and oxidation. These "core materials" can be antioxidants, flavors or even vitamins, and are involved by other compounds called "wall materials" 1.

Due to the importance of microencapsulation and its application, nowadays there is a growing search for cheaper new substances which can be used as efficient WMs. The BSY presents great potential as wall material because of its emulsifying proteins and overall composition (proteins, vitamins and minerals). It is the second most relevant byproduct from the brewing industry, being a low cost material ${ }^{2}$ and thus its processing is a sustainable residue management option.

The objective of the present work was to study the application of BSY hydrolyzed precipitate as WM for microencapsulation of food compounds by determining the CC and PC characteristics from the BSY and also from the microparticles produced by spray drying.

\section{Results and Discussion}

The BSY precipitate, after protein hydrolysis, was first characterized before being used as WM for microencapsulation and its results of $\mathrm{CC}$ and $\mathrm{PC}$ analyses are shown at Chart 1 . The elevated content of proteins indicates that this material has potential and it should be further studied to access its emulsifying capacity.

Chart 1. Centesimal Composition of brewer's spent yeast hydrolyzed precipitate

\begin{tabular}{|c|c|c|c|c|c|}
\hline $\begin{array}{c}\text { Total } \\
\text { solids }\end{array}$ & Proteins & $\begin{array}{c}\text { Total } \\
\text { sugars }\end{array}$ & Ash & Fibers & Lipids \\
\hline $\begin{array}{c}26.3 \\
\pm 0.3\end{array}$ & $\begin{array}{c}43.0 \pm \\
0.3\end{array}$ & $37.2 \pm 1.0$ & $5.1 \pm 0.0$ & $18.4 \pm 0.6$ & $<1$ \\
\hline
\end{tabular}

After wall material characterization, the AA was

chosen to be microencapsulated because of its hydrophilic characteristic and stability when submitted to quickly heating, as occurs in spray dryer. The surface charge and surface tension of the WM (Chart 2) influenced the decision of the dispersion's $\mathrm{pH}$ for the drying process. $\mathrm{pH} 6$ was chosen because, at this $\mathrm{pH}$, the $A A$ is still stable and WM shows relative higher surface charge, what improves the repulsion between the WM particles, keeping them separated. The lower surface tension indicates the lipophilic parts of the proteins were exposed by the hydrolysis, elevating the possibilities of hydrophobic/hydrophilic interactions between the compounds of the WM, causing a more efficient involvement and microencapsulation of $A A$.

Chart 2. Physicochemical characteristics of brewer's spent yeast hydrolyzed precipitate

\begin{tabular}{|c|c|c|}
\hline $\mathbf{T}_{\mathbf{g}}\left({ }^{\circ} \mathbf{C}\right)$ & $\begin{array}{c}\text { Surface charge - } \mathbf{p H} \mathbf{6} \\
(\mathbf{m V})\end{array}$ & Surface tension - pH 6 \\
\hline $70.1 \pm 3.3$ & $-11.0 \pm 0.6$ & $40.7 \pm 0.1$ \\
\hline
\end{tabular}

Efficiency value at Chart 3 is in agreement with the literature and the yield is higher than the average observed for the Mini Spray Dryer B-290 (Büchi, Flawil, Switzerland) in other studies. The moisture content and the water activity of the particles were low, indicating the product is stable against microbiological degradation.

Chart 3. Results of the microencapsulation by spray dryer and physicochemical data from the particles

\begin{tabular}{|c|c|c|c|c|c|}
\hline $\begin{array}{c}\text { Yield } \\
(\%)\end{array}$ & $\begin{array}{c}\text { Efficiency } \\
(\%)\end{array}$ & $\begin{array}{c}\text { Moisture } \\
(\%)\end{array}$ & $\begin{array}{c}\text { Water } \\
\text { Activity }\end{array}$ & $\begin{array}{c}\text { Diameter } \\
(\mu \mathrm{m})\end{array}$ & $\mathbf{T}_{\mathbf{g}}\left(^{\circ} \mathbf{C}\right)$ \\
\hline $\begin{array}{c}63.9 \pm \\
0.8\end{array}$ & $\begin{array}{c}100.0 \pm \\
6.95\end{array}$ & $3.0 \pm 0.1$ & $0.1 \pm 0.0$ & $1.1-13.5$ & $\begin{array}{c}72.3 \pm \\
0.3\end{array}$ \\
\hline
\end{tabular}

Chart 3 also shows the variation of mean particle diameters, which is higher than the obtained in related works, probably because the yeast compounds cause bigger particles. Finally, the $\mathrm{T}_{\mathrm{g}}$ was kept high $\left(72.3^{\circ} \mathrm{C}\right)$ after the atomization, as the value obtained for WM (70.1 $\left.{ }^{\circ} \mathrm{C}\right)$, indicating the particles may be stable at room temperature.

\section{Conclusions}

The BSY hydrolyzed precipitate showed great potential on the microencapsulation of $A A$, providing elevated values of yield and efficiency. The particles obtained had low moisture and water activity, in addition to a high $\mathrm{T}_{\mathrm{g}}$, indicating high particles' stability

\footnotetext{
${ }^{1}$ QUEK, S. Y.; CHEN, Q.; SHI, J. Microencapsulation of Food Ingredients for Functional Foods. In: SHI, J. Functional Food Ingredients and Nutraceuticals: Processing Technologies. $2^{\mathrm{a}}$ Ed. CRC Press, 2015. cap. 10, p. 267-318.

${ }^{2}$ SHI, G. et al. Characterization of yeast cells as a microencapsulation wall material by Fourier-transform infrared spectroscopy. Vibrational Spectroscopy, v. 53 , n. 2, p. 289-295, abr. 2010
} 